\title{
Salicylic acid and jasmonic acid can suppress green and blue moulds of citrus fruit and induce the activity of polyphenol oxidase and peroxidase
}

\author{
Anam Moosa $^{1 *}$, Shahbaz Talib Sahi ${ }^{1}$, Sajid Aleem Khan ${ }^{1}$, Aman Ullah Malik ${ }^{2}$
}

${ }^{1}$ Department of Plant Pathology, University of Agriculture, P.O. Box 38040, Faisalabad, Pakistan

${ }^{2}$ Institute of Horticulture Sciences, University of Agriculture, P.O. Box 38040, Faisalabad, Pakistan

\begin{abstract}
The ability of salicylic acid and jasmonic acid to suppress post-harvest infection with green mould Penicillium digitatum and blue mould P. italicum on three citrus species Citrus reticulata 'Kinnow', C. limon 'Meyer Lemon', and C. limetta 'Mosambi' was evaluated in a dose-response study. Salicylic acid (SA) and jasmonic acid (JA) were applied to the fruits as a post-harvest dip treatment followed by wound inoculation with the pathogens. Both resistance inducers caused a significantly lower disease severity compared with the infected but non-treated control, whereas disease incidence was not significantly lower than in the control. The efficacy of both SA and JA in reducing disease severity was concentration-dependent; the use of higher concentrations resulted in a greater degree of suppression. All the Citrus species tested in this study showed different responses in terms of disease development. C. limon 'Meyer Lemon' showed the highest disease development, and C. limetta 'Mosambi' the lowest. To get an insight into the mechanisms underlying the increase in resistance, the activity of defence-related enzymes - peroxidase (POD) and polyphenol oxidase (PPO) - was recorded in SA- and JA-treated fruit peelings. The activity of both enzymes was directly proportional to the concentration of the SA and JA applications. The highest activity of PPO and POD was observed in C. reticulata 'Kinnow' and the lowest in C. limon 'Meyer Lemon' fruits. This study is the first to document an increase in the activity of PPO and POD in SA- and JA-treated Citrus species in the presence of blue mould and green mould pathogens.
\end{abstract}

Key words: enzymes, Penicillium digitatum, P. italicum, post-harvest, resistance inducers

\begin{abstract}
Abbreviations:
BM - blue mould, GM - green mould, JA - jasmonic acid, POD - peroxidase, PPO - polyphenol oxidase, $\mathrm{RH}$ - relative humidity, SA - salicylic acid
\end{abstract}

\section{INTRODUCTION}

Fresh fruit exports are very important for a country's economy and citrus fruits are an important part of all fresh fruit exports in the world (Ceylan et al., 2018). Fungal decay impairs fruit quality and causes major economic losses (Kahramanoğlu et al., 2018). Citrus fruits are susceptible to various post-harvest fungal diseases that cause significant economic losses during storage. Among them, green mould, caused by Penicillium digitatum Sacc., and blue mould, caused by Penicillium italicum Wehmer, are the most damaging post-harvest pathogens (Moscoso-Ramírez and Palou, 2013). P. digitatum can cause up to $90 \%$ of total post-harvest decay in

\footnotetext{
*Corresponding author. 
storage (Kinay et al., 2007). P. italicum is also of great economic significance because it can grow during post-harvest storage at temperatures of $<4^{\circ} \mathrm{C}$ (Wyatt and Parish, 1995).

Currently, post-harvest decay of citrus fruits is controlled mainly through the use of post-harvest treatments with synthetic fungicides. However, public concern about chemical toxicity, health problems, and development of fungicide resistance has amplified the need to develop ecologically friendly alternatives for controlling post-harvest decay (Panebianco et al., 2015).

Inducing resistance against phytopathogens in plants by the application of biological elicitors (Droby et al., 2002; Nantawanit et al., 2010) and physical elicitors (Liu et al., 2010) is a promising approach (Iqbal et al., 2012). Defence induction has provided encouraging results against several fungal pathogens of fruit crops (Sticher et al., 1997; Qin et al., 2003). Salicylic (SA) and jasmonic (JA) acids are natural disease resistance inducers that stimulate antifungal activity against various pathogens of fruit crops such as mango, pear, and citrus fruits (Shaat and Galal, 2004). In addition to inducing resistance in plants, SA and JA also play key roles in the regulation of plant growth and development (Yao and Tian, 2005).

Green mould and blue mould pathogens affect almost all citrus fruits. However, the efficacy of resistance inducers against Penicillium rot of citrus fruits has not been systematically studied yet (Iqbal et al., 2012), and the mechanism by which SA and JA induce defence in citrus fruits is not extensively studied. Inducers trigger expression of defencerelated enzymes such as chitinase, peroxidase and polyphenol oxidase (Meena et al., 2001).

Little is known about host-Penicillium interaction in Citrus species. The research has mainly been focused on controlling Penicillium species and has not explained their interaction with various citrus hosts such as lemon, lime, mandarin, orange and grapefruit. The interaction of citrus species and Penicillium species has not been specified yet (Louw and Korsten, 2015). Macarisin et al. (2007) reported the pathogenicity of Penicillium expansum on grapefruits, lemons and oranges, and explained that the potential of citrus fruits to produce reactive oxygen species is correlated with hindered development of infection. Similarly, Vilanova et al. (2012) explained the potential of Penicillium expansum to cause infection in 'Valencia' and 'Navelina' oranges. P. expansum produced larger lesions on 'Navelina' oranges than on 'Valencia'.
Therefore, there is a need to study the interaction of Citrus spp. with Penicillium species to understand how different hosts respond to various treatments during storage and commercial application.

In this study, we hypothesized that SA and JA were able to elicit plant defence and alter the activity of defence-related enzymes, POD and PPO, in three Citrus species. The aims of the study were to 1) evaluate the ability of SA and JA to induce disease resistance in citrus fruits against green mould and blue mould pathogens, 2) investigate the influence of SA and JA on the activity of defencerelated enzymes, POD and PPO, in citrus fruits, and 3) investigate the response of Citrus species to SA and JA treatments.

\section{MATERIAL AND METHODS}

\section{Plant material}

Healthy, blemish-free and freshly harvested citrus fruits were obtained from the "9 Square" germplasm orchard of the University of Agriculture, Faisalabad, Pakistan (UAF). Three different citrus species with commercial and storage value were selected for the study: Citrus reticulata 'Kinnow', C. limon 'Meyer Lemon', and C. limetta 'Mosambi'.

\section{Fungal cultures and inoculum}

P. digitatum and P. italicum were isolated on PDA from decaying fruits of Citrus reticulata 'Kinnow' collected from the "9 square" orchard of UAF. The sequences of $P$. digitatum (MH608340) and $P$. italicum (MH612928) were submitted to GenBank. The cultures were maintained on potato dextrose agar (PDA) at $25 \pm 2{ }^{\circ} \mathrm{C}$. The conidial suspension from 6-day-old cultures was prepared in sterilized distilled water and adjusted to $1 \times 10^{5}$ spores $\mathrm{mL}^{-1}$.

\section{Assessment of the effects of SA and JA on disease development}

Antifungal activity of JA and SA against $P$. italicum and $P$. digitatum was evaluated by the method of Iqbal et al. (2012). Blemish-free citrus fruits of uniform size were harvested, surface-sterilized by submersing in $1 \%$ sodium hypochlorite $(\mathrm{v} / \mathrm{v})$ for 10 seconds, and then rinsed with sterile distilled water and air-dried. Aqueous solutions of SA (2 $\mathrm{mM}, 4 \mathrm{mM}, 6 \mathrm{mM}$, and $8 \mathrm{mM}$ ) and JA $(1 \mathrm{mM}, 2 \mathrm{mM}, 3 \mathrm{mM}$, and $4 \mathrm{mM})$ in distilled water were amended with $0.5 \%$ Tween $80(\mathrm{v} / \mathrm{v})$. Prior to inoculation, the fruits were dipped in JA or SA solutions for $15 \mathrm{~min}$. A set of 5 replicate fruits per species (replicates) were wounded (to a depth 
of approx. $2 \mathrm{~mm}$ ) in each treatment by piercing the pericarp with a sterilized metal wire. After $24 \mathrm{~h}$ of incubation at $25 \pm 2^{\circ} \mathrm{C}$, the wounds were inoculated with $10 \mu \mathrm{L}$ of a suspension of $1 \times 10^{5}$ spores $\mathrm{mL}^{-1}$ from 6-day-old culture of one of the pathogens, using a micropipette. The fruits were kept in sterilized autoclavable square plastic boxes and incubated at $25 \pm 2^{\circ} \mathrm{C}$ for $8 \mathrm{~d}$ in a $90 \%$ relative humidity $(\mathrm{RH})$ chamber. The experimental layout was completely randomized. The experiment was repeated twice with a set of 5 replicates per species each time and the average effect of 15 replicates was considered. Disease incidence was determined using the formula given by Sukorini et al. (2013):

$$
\text { Disease incidence }=\frac{\text { No. of infected fruits }}{\text { Total No. of fruits }} \times 100
$$

Disease severity was calculated using the formula of Masood et al. (2010):

Disease severity $=$ Infected area $/$ Total area $\times 100$.

\section{Effect of SA and JA on PPO and POD activities in citrus fruit peel}

\section{Enzyme extraction}

Peelings were obtained from each of five fruits per treatment. Extracts of the peelings were prepared using a method described by Coseteng and Lee (1987), with modifications. The peel of each fruit was ground in $0.2 \mathrm{M}$ potassium phosphate $\left(\mathrm{KH}_{2} \mathrm{PO}_{4}\right)$ buffer of pH 6.8 using a pestle and mortar to obtain a homogenate. The homogenate was filtered through a sintered glass funnel and centrifuged at $12,000 \mathrm{~g}$ at $4^{\circ} \mathrm{C}$ for $10 \mathrm{~min}$. The decanted supernatant was collected to determine the enzyme activity.

\section{$P O D$ and $P P O$ activity assay}

Peroxidase activity in infected and healthy fruit peelings was determined by using a reaction mixture consisting of $5 \mathrm{mM}$ guaiacol and $5 \mathrm{mM}$ $\mathrm{H}_{2} \mathrm{O}_{2}$ in $0.2 \mathrm{M} \mathrm{KH}_{2} \mathrm{PO}_{4}$ buffer of $\mathrm{pH}$ 6.8. The reaction was carried out by mixing $800 \mu \mathrm{L}$ of the reaction mixture and $200 \mu \mathrm{L}$ of peel extracts. To determine POD activity, $100 \mu \mathrm{L}$ of each sample was loaded in an ELISA plate reader and absorbance was recorded at $470 \mathrm{~nm}$ (Siegel and Galston, 1967). Protein content of the extracts was determined using the method of Bradford (Bradford, 1976), with bovine serum albumin as a standard. One unit of POD activity was measured as one unit increase in absorbance at $470 \mathrm{~nm}$ per min. The POD activity was expressed as $\min ^{-1} \mathrm{~g}^{-1}$ of fresh weight of the fruit.

The activity of PPO was assessed by using exogenous catechol substrate. Enzyme activity was measured using the method of Kumar et al. (2008) with some modifications. The reaction mixture consisted of $500 \mu \mathrm{L}$ of $50 \mathrm{mM}$ catechol, $2.5 \mathrm{~mL}$ of $0.2 \mathrm{M} \mathrm{KH}_{2} \mathrm{PO}_{4}$ buffer at $\mathrm{pH} 6.8,500 \mu \mathrm{L}$ of chilled acetone and $200 \mu \mathrm{L}$ of extraction sample. The blank sample consisted of $1 \mathrm{~mL}$ catechol substrate solution. Absorbance was measured at $420 \mathrm{~nm}$ with a spectrophotometer; one unit of PPO activity was equivalent to an increase of 0.01 absorbance units $\mathrm{min}^{-1}$ at $420 \mathrm{~nm}$. The PPO activity in citrus fruit peelings was expressed as units of PPO activity $\mathrm{min}^{-1} \mathrm{~g}^{-1}$ of fresh weight. The enzyme activity was determined in five fruits from each treatment.

\section{Statistical analysis}

The experimental data were subjected to two-way ANOVA using the statistical package Statistix (ver. 8.1) (available at https://www.statistix.com/). Separations of the means for disease incidence and disease severity were performed with Tukey's HSD test at $p=0.05$ to determine significant differences among the treatments. Standard errors were calculated for all the data and expressed as mean \pm SE. All assumptions of ANOVA were checked to validate the statistical analysis.

\section{RESULTS AND DISCUSSION}

\section{Effect of $S A$ and $J A$ on disease incidence and severity}

The preventive treatment of the fruits in aqueous solutions of SA and JA decreased disease severity and incidence of green mould and blue mould on all the fruits in a concentration-dependent manner (Tab. 1). SA at $8 \mathrm{mM}$ and JA at $4 \mathrm{mM}$ showed the highest suppression in disease severity and incidence of both moulds on $C$. reticulata 'Kinnow', C. limon 'Meyer Lemon', and C. limetta 'Mosambi' fruits, compared to the inoculated control. At $0 \mathrm{mM}$ (untreated infected plants), 100\% disease incidence and highest disease severity were observed in all the species. According to ANOVA, the effect of species (A), concentration (B), treatment $(\mathrm{C})$ and the interaction of $\mathrm{A} \times \mathrm{C}$ was significant on disease incidence and severity of both moulds (Tab. 2). The interactions $\mathrm{A} \times \mathrm{B}, \mathrm{B} \times \mathrm{C}$ and $\mathrm{A} \times \mathrm{B} \times \mathrm{C}$ had a significant effect on disease severity, while their effect was non-significant on disease incidence at $p=0.05$. The interaction of treatment and species $(\mathrm{A} \times \mathrm{C})$ was significant on both disease incidence and severity, indicating that the species were responsive to the treatment. The suppressive effect of both resistance inducers on disease incidence and severity generally increased 


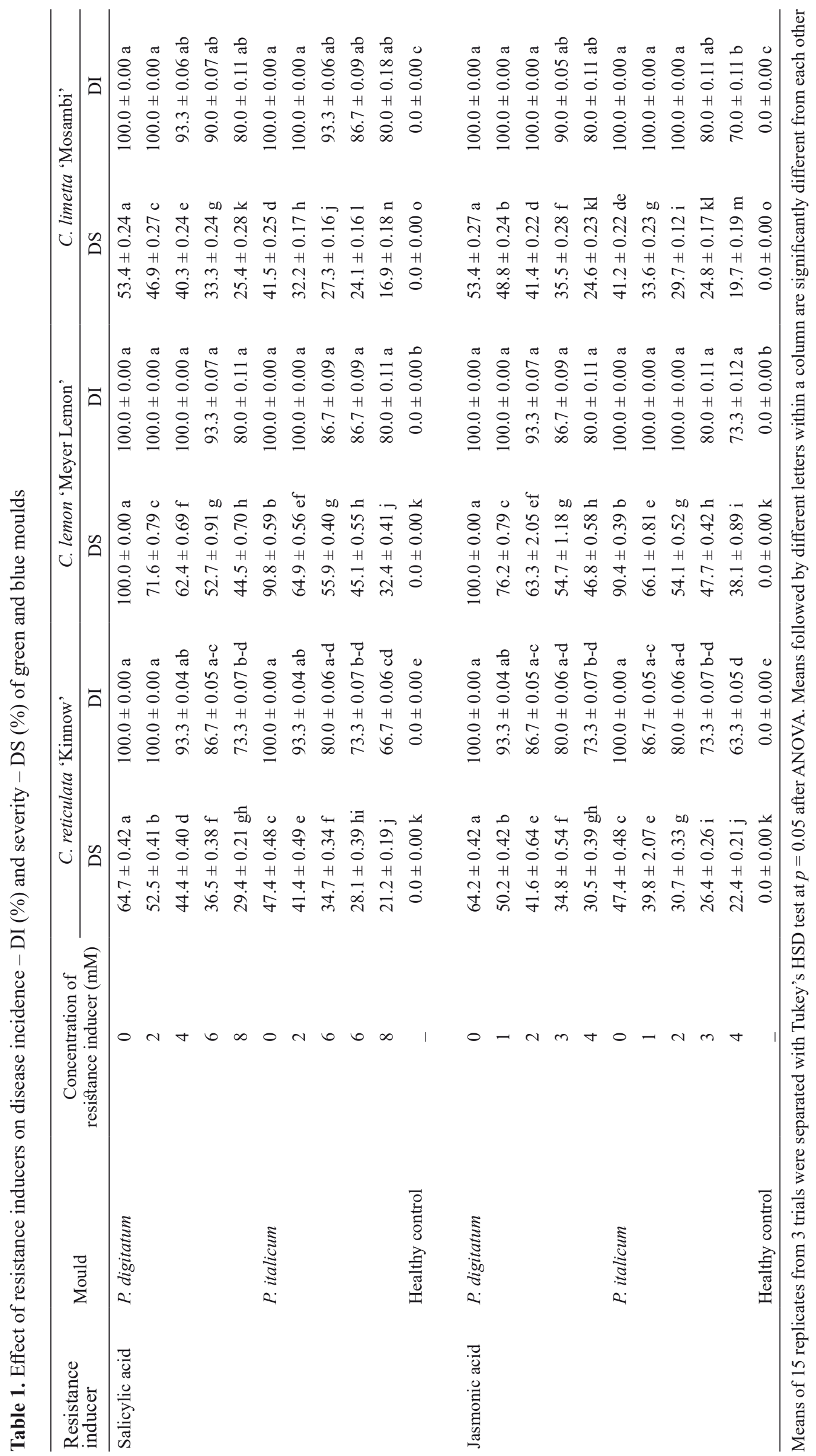


Table 2. ANOVA for disease incidence and severity

\begin{tabular}{|c|c|c|c|c|c|c|}
\hline \multirow{2}{*}{ Source } & \multicolumn{3}{|c|}{ DS } & \multicolumn{3}{|c|}{ DI } \\
\hline & MS & $\mathrm{F}$ & $p$-value & MS & $\mathrm{F}$ & $p$-value \\
\hline \multicolumn{7}{|l|}{ Main effect } \\
\hline Species (A) & 32403 & 9434.48 & $0.00^{*}$ & 1.7101 & 45.52 & $0.00^{*}$ \\
\hline Concentration (B) & 60629 & 17652.7 & $0.00^{*}$ & 0.4254 & 11.32 & $0.00^{*}$ \\
\hline Treatment (C) & 162448 & 47298.6 & $0.00^{*}$ & 60.5543 & 1611.83 & $0.00^{*}$ \\
\hline \multicolumn{7}{|l|}{ Interaction effect } \\
\hline $\mathrm{A} \times \mathrm{B}$ & 2077 & 604.70 & $0.00^{*}$ & 0.0316 & 0.84 & $0.56^{\mathrm{ns}}$ \\
\hline $\mathrm{A} \times \mathrm{C}$ & 3095 & 901.20 & $0.00^{*}$ & 0.1871 & 4.98 & $0.00^{*}$ \\
\hline $\mathrm{B} \times \mathrm{C}$ & 5765 & 1678.53 & $0.00^{*}$ & 0.0611 & 1.63 & $0.11^{\mathrm{ns}}$ \\
\hline $\mathrm{A} \times \mathrm{B} \times \mathrm{C}$ & 232 & 67.45 & $0.00^{*}$ & 0.0106 & 0.28 & $1.00^{\mathrm{ns}}$ \\
\hline Error & 3 & & & 0.0376 & & \\
\hline
\end{tabular}

*indicates significant, and ns non-significant effect at $p=0.05$, ANOVA.

$\mathrm{DS}=$ Disease severity, $\mathrm{DI}=$ Disease incidence, $\mathrm{MS}=$ Mean sum of squares

with increasing concentration. This research demonstrates the potential of SA and JA to reduce the disease incidence and severity of green mould and blue mould on harvested citrus fruits. The reduction in disease severity and incidence of blue mould and green mould can be attributed to defence activation upon treatment with the resistance inducers. Our results correspond with those of Iqbal et al. (2012), who reported that dip treatment in 8- and 10-mM salicylic acid solutions significantly inhibited the development of green mould and blue mould on C. sinensis 'Lane Late' fruit. However, the concentrations used in their research were generally higher compared to those in our study. Unlike the results of this study, where the application of elicitors could not completely reduce disease development, Strobel and Porter (2005) reported complete absence of growth of several fruit-infecting fungi at higher concentrations of SA $(>10 \mathrm{mM})$. The activity of both resistance inducers was found to be concentration-dependent, which is in agreement with the results of He et al. (2017), who reported that SA inhibited the growth of Colletotrichum gloeosporioides in a concentrationdependent manner. The direct inhibitory effect of SA at different concentrations has been reported against many plant pathogens (Mandal et al., 2009; Dessalegn et al., 2013). The result further supports the potential of resistance inducers as preventive treatments and disease suppressors. All the species tested in this study showed different responses to treatment. Disease incidence and severity varied across all the species. C. lemon 'Meyer Lemon' showed the highest, and C. limetta 'Mosambi' the lowest, disease incidence and severity of both moulds at all the concentrations. The green and blue moulds were the most aggressive on C. limon 'Meyer Lemon'. This could be explained on the basis of the large variation among the species tested. Louw and Korsten (2015) had reported varied degrees of aggressiveness and pathogenicity of Penicillium species on various Citrus species and cultivars in their study. The variation in disease development on species can be attributed to several factors such as cultural practices, harvesting season, fruit maturity, nutrient status, and postharvest environment (Eckert and Eaks, 1989).

Although the resistance inducers had a significant suppressive effect on disease severity of both moulds on all the species, disease development was not completely halted. Previously, MoscosoRamírez and Palou (2013) had raised the concern on the inclusion of resistance inducers in commercial packing houses due to the relatively low efficacy in suppressing disease development. Hence, it is still questionable whether to include resistance inducers in commercial post-harvest decay control programmes because any symptom development is likely to lead to rejection by consumers. However, resistance inducers could find a role in disease management as one component of an integrated risk reduction strategy, particularly in situations where synthetic chemical fungicides do not provide an acceptable option.

\section{Assessment of the activity of PPO and POD after treatment with $S A$ and $J A$}

The activity of PPO and POD was significantly affected after treatment with the resistance inducers SA and JA (Figs 1, 2 and 3). A similar pattern of change in the activity was observed in response to both SA and JA in all the species. Both SA and JA 


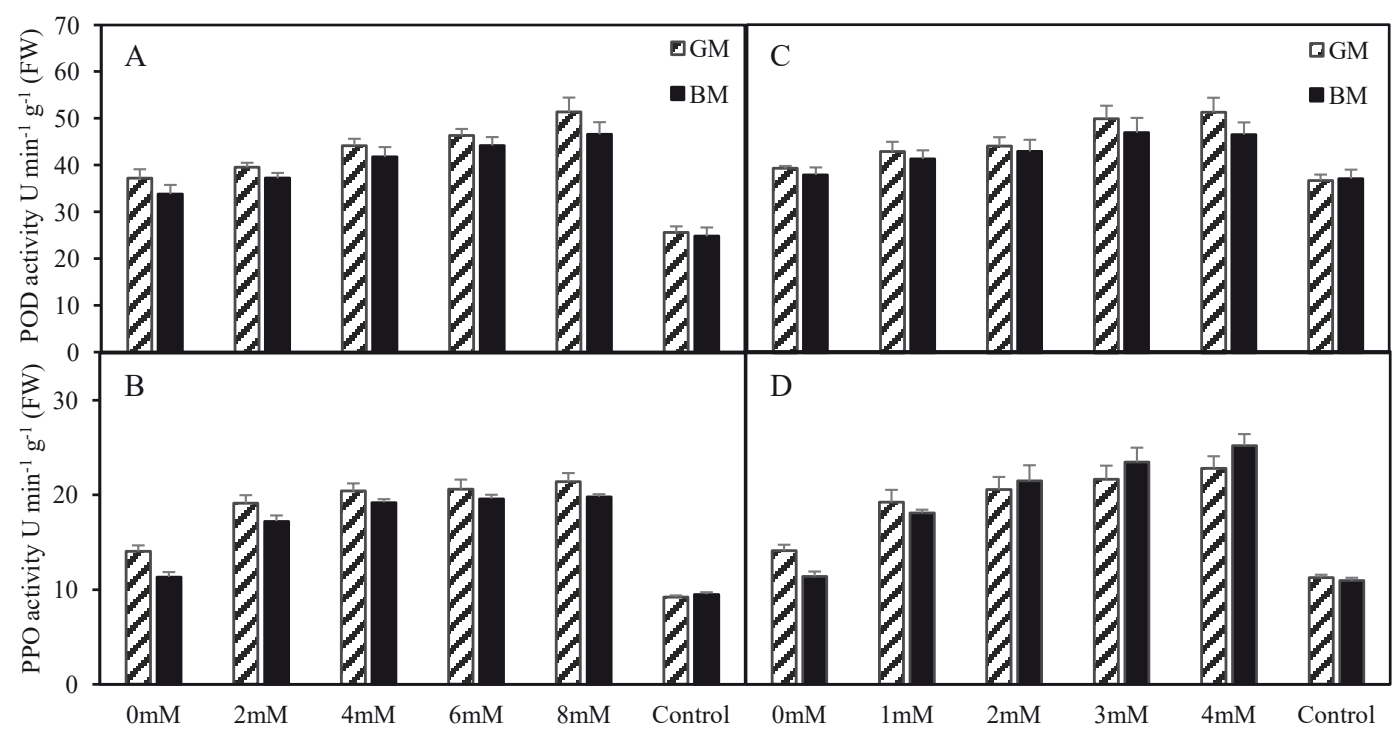

Figure 1. Changes in polyphenol oxidase (PPO) and peroxidase (POD) activities in peelings of C. reticulata 'Kinnow' fruit treated with salicylic acid (A, B) and jasmonic acid (C, D), and infected with green mould (GM) and blue mould (BM), and stored at $25 \pm 2{ }^{\circ} \mathrm{C}$ and $90 \%$ relative humidity for 8 days. Values are means of 5 replicates; error bars represent the standard error of the mean

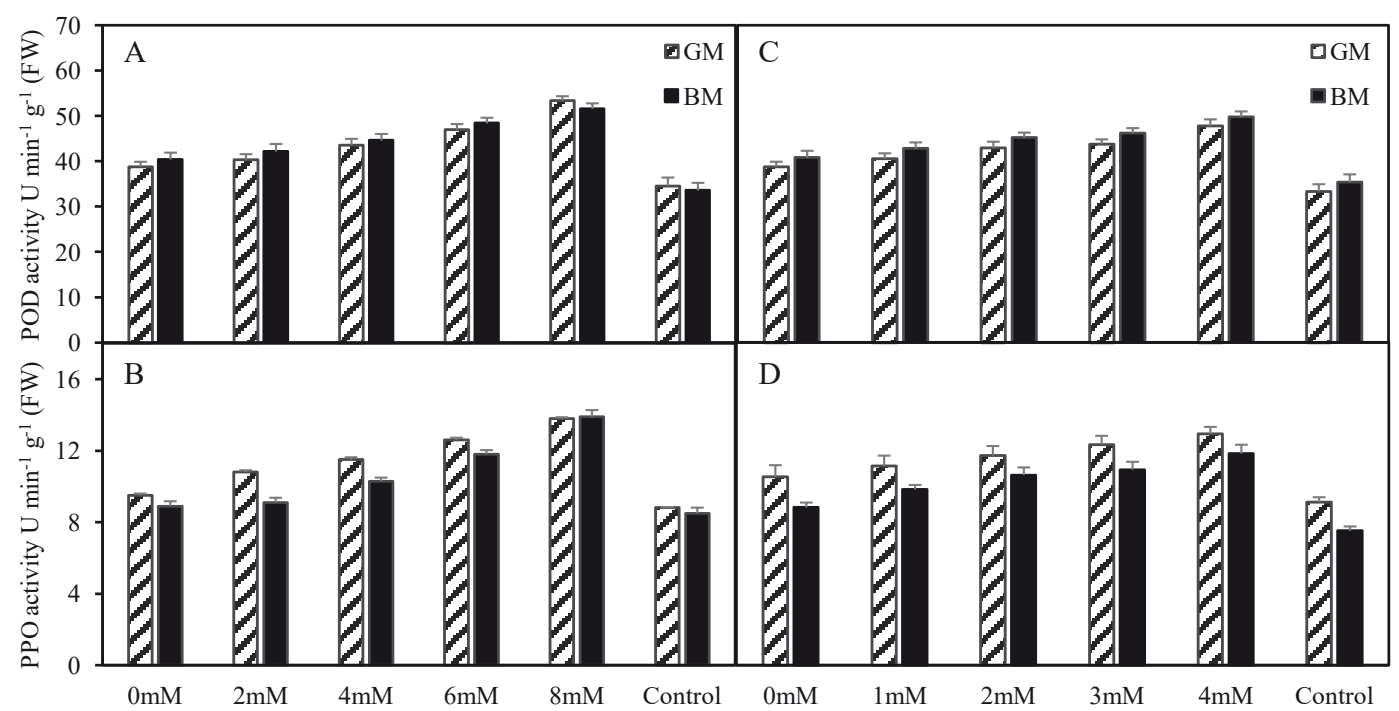

Figure 2. Changes in polyphenol oxidase (PPO) and peroxidase (POD) activities in peelings of $C$. limetta 'Mosambi' fruit treated with salicylic acid (A, B) and jasmonic acid (C, D), and infected with green mould (GM) and blue mould (BM), and stored at $25 \pm 2{ }^{\circ} \mathrm{C}$ and $90 \%$ relative humidity for 8 days. Values are means of 5 replicates; error bars represent the standard error of the mean

caused an increase in PPO and POD activities in the citrus species infected with green mould and blue mould in a concentration-dependent manner. The treatment with $8 \mathrm{mM} \mathrm{SA}$ and $4 \mathrm{mM} \mathrm{JA}$ caused highest activity of PPO and POD in the peelings of all the fruits. The lowest activity of PPO and POD was recorded in healthy control treatments of all the types of fruit. All the species showed different degrees of PPO and POD activity. The highest activity of PPO and POD was observed in $C$. reticulata 'Kinnow', and the lowest activity was observed in C. limon 'Meyer Lemon'. The analysis of variance for PPO and POD activities indicated that the main effect of species (A) and treatment $(C)$ was significant on both enzymes, while the effect of concentration (B) was significant on PPO, but non-significant on POD at $p=0.05$ (Tab. 3). The two-way interactions $A \times B$ and $A \times C$ were significant, while $B \times C$ was non-significant on POD and PPO activities. The three-way interaction $\mathrm{A} \times \mathrm{B} \times \mathrm{C}$ was non-significant on $\mathrm{POD}$, but significant on PPO activity. The activity of PPO and POD in 


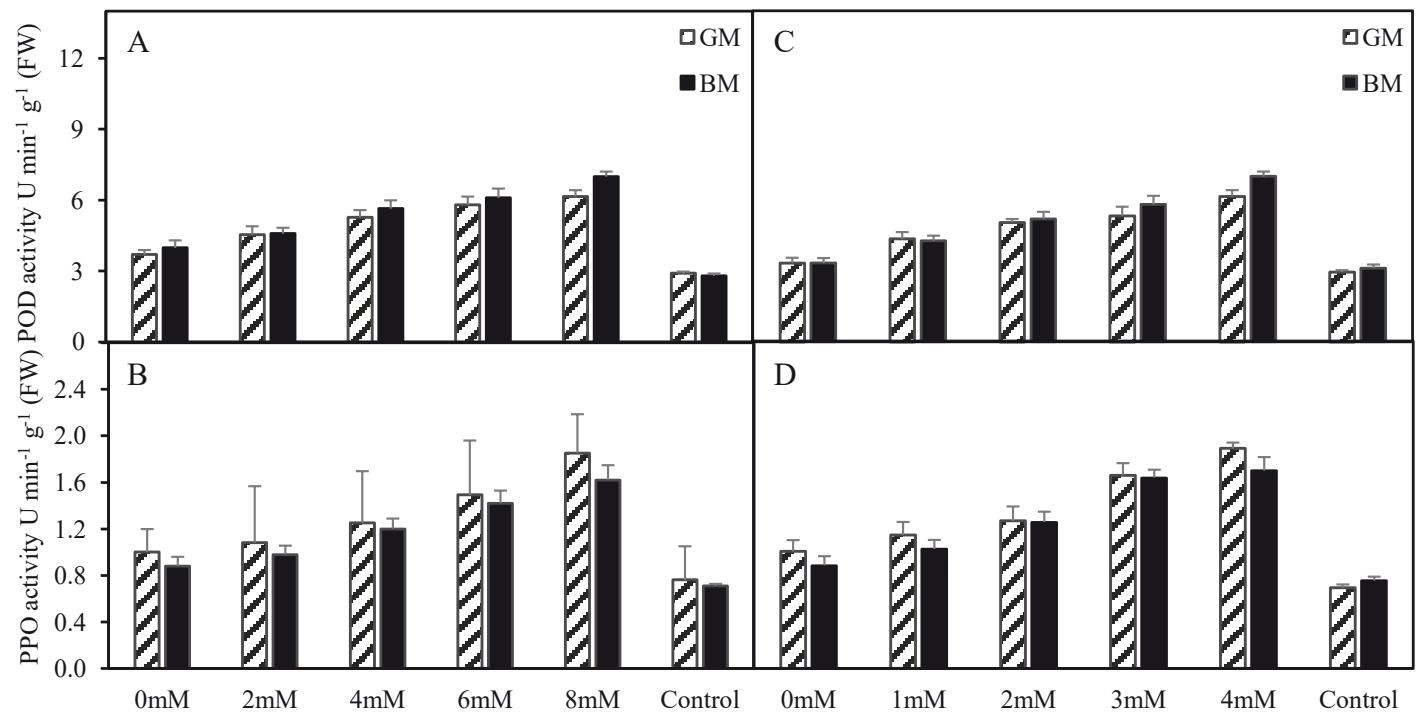

Figure 3. Changes in polyphenol oxidase (PPO) and peroxidase (POD) activities in peelings of $C$. limon 'Meyer Lemon' fruit treated with salicylic acid (A, B) and jasmonic acid (C, D), and infected with green mould (GM) and blue mould (BM), and stored at $25 \pm 2^{\circ} \mathrm{C}$ and $90 \%$ relative humidity for 8 days. Values are means of 5 replicates; error bars represent the standard error of the mean

SA- and JA-treated fruits was generally increased with increasing concentration. PPO and POD activities were significantly higher in the treated fruits compared to healthy and infected control fruits. These results indicate an upsurge in the activity of both enzymes after treatment with the resistance inducers. Post-harvest disease resistance is accompanied by the activation of a series of defence responses against fungal pathogens, such as the generation of reactive oxygen species (ROS) and the phenylpropanoid pathway (Kuć, 2001). Reactive oxygen species play a key role in mediating host-plant defence (Torres et al., 2006; Ottmann et al., 2009). Peroxidase is an important enzyme that works along with other enzymes to scavenge ROS. It plays a key role during the formation of lignin, which is involved in cell-wall reinforcement leading to increased resistance against many pathogens, and alteration of the antioxidant activity of citrus fruits against Penicillium infection (Ballester et al., 2006).

In the present study, PPO and POD activities were significantly increased by the application of $\mathrm{SA}$ and $\mathrm{JA}$ in a concentration-dependent manner, compared to infected controls. The increase in PPO and POD activities was directly proportional to the extent of disease suppression. It had been previously suggested that resistance inducers could enhance the activity of PPO against various fruit pathogens (Qin et al., 2003; Yao and Tian, 2005). Several reports had stated that SA increased the activity of defence-related enzymes such as phenylalanine lyase and polyphenol oxidase (Qin et al., 2003; Cao et al., 2013; Ojaghian et al., 2013). Recent reports have also stated that the increase in disease resistance was directly associated with an increase in POD activity (Yu et al., 2008; Xu et al., 2008; Tareen et al., 2012). However, it is important to understand the mechanisms that underlie defence activity. The phenylpropanoid pathway is a key metabolic pathway; during this pathway the plant produces a variety of phenolic compounds such as flavonoids, lignin, and phenolics that are directly involved in disease resistance. PPO is a key enzyme that is involved in lignification of the plant cell wall and conversion of phenols into quinones that are highly toxic and can hinder pathogen development (Mohammadi and Kazemi, 2002; Zheng and Tian, 2006).

All the tested species showed varying degrees of PPO and POD activity. The highest activity of PPO and POD was observed in C. reticulata 'Kinnow' and the lowest activity was observed in $C$. limon 'Meyer Lemon'. The variation in enzyme activity among various fruit species had been explained in previous studies. Similar to our findings, Lee et al. (1990) had found varying PPO activity in different peach cultivars. According to our study, the activity of PPO and POD in citrus fruits determined their potential to suppress disease development. The enzyme activity was correlated with disease suppression in all the cultivars. It had been previously explained that differential expression of POD and PPO was correlated with differential expression 
Table 3. ANOVA for POD and PPO activities

\begin{tabular}{|c|c|c|c|c|c|c|}
\hline \multirow{2}{*}{ Source } & \multicolumn{3}{|c|}{ POD } & \multicolumn{3}{|c|}{ PPO } \\
\hline & MS & $\mathrm{F}$ & $p$-value & MS & $\mathrm{F}$ & $p$-value \\
\hline \multicolumn{7}{|l|}{ Main effect } \\
\hline Species (A) & 49903.6 & 13833.3 & $0.00^{*}$ & 7843.11 & 324.90 & $0.00^{*}$ \\
\hline Concentration (B) & 5.7 & 1.59 & $0.19^{\text {ns }}$ & 16.47 & 6.81 & $0.00^{*}$ \\
\hline Treatment (C) & 25.4 & 7.05 & $0.00^{*}$ & 195.82 & 80.2 & $0.00^{*}$ \\
\hline \multicolumn{7}{|l|}{ Interaction effect } \\
\hline $\mathrm{A} \times \mathrm{B}$ & 69.6 & 19.29 & $0.00^{*}$ & 11.87 & 4.90 & $0.00^{*}$ \\
\hline $\mathrm{A} \times \mathrm{C}$ & 413.9 & 114.75 & $0.00^{*}$ & 67.99 & 28.09 & $0.00^{*}$ \\
\hline $\mathrm{B} \times \mathrm{C}$ & 3.4 & 0.94 & $0.51^{\mathrm{ns}}$ & 1.87 & 0.77 & $0.67^{\mathrm{ns}}$ \\
\hline $\mathrm{A} \times \mathrm{B} \times \mathrm{C}$ & 6.3 & 1.75 & $0.01^{*}$ & 3.53 & 1.46 & $0.08^{\text {ns }}$ \\
\hline Error & 3.6 & & & 2.42 & & \\
\hline
\end{tabular}

*indicates significant, and ns non-significant effect at $p=0.05$, ANOVA.

$\mathrm{POD}=$ Peroxidase, $\mathrm{PPO}=$ Polyphenol oxidase, $\mathrm{MS}=$ Mean sum of squares

of disease resistance (Ballester et al. 2006). The present study indicates a clear relationship between an increase in POD and PPO activities and disease resistance against green mould and blue mould in the investigated citrus species.

In conclusion, the results of the study showed that SA and JA significantly reduced the severity of green mould and blue mould infection on all the tested citrus species. However, SA and JA did not significantly reduce disease incidence. It is reasonable to hypothesize that SA and JA induced an increase in the activity of PPO and POD that helped to suppress the development of green mould and blue mould. The response of the species tested in this study explains how different Citrus species respond when treated with resistance inducers. It is important to further study and understand the effect of resistance inducers on citrus species/ cultivars during commercial storage. Further investigations should focus on the use of SA and JA as a component of a programme for managing green and blue moulds along with other practices at the commercial level to develop management protocols.

\section{CONCLUSIONS}

1. Salicylic acid and jasmonic acid suppressed the development of green and blue moulds of citrus fruits in a dose-dependent manner.

2. Resistance inducers caused an upsurge in the activity of polyphenol oxidase and peroxidase in citrus fruits.

3. The suppressive activity of the resistance inducers was directly correlated with the increased activity of polyphenol oxidase and peroxidase.

4. The tested Citrus species showed different responses in terms of disease development and enzyme activity.

5. Salicylic acid and jasmonic acid can be included in integrated disease management of green and blue moulds of citrus fruits.

\section{ACKNOWLEDGEMENT}

The authors are thankful to Dr. Mark Lawrence Gleason, Professor, Iowa State University, Ames, Iowa, USA for reviewing this manuscript technically and grammatically.

\section{FUNDING}

The authors acknowledge the financial support provided by Higher Education Commission of Pakistan under "HEC Indigenous M. Phil leading to $\mathrm{Ph}$. D fellowship program" pin \# 2AV2-151 in support of this work.

\section{AUTHOR CONTRIBUTIONS}

A.M. - planned, conducted the experiments and wrote the manuscript; S.T.S. - planned and designed the experiment layout; S.A.K. - helped in statistical analysis and to do the study; A.U.M. - helped to write the manuscript and to select experimental units.

\section{CONFLICT OF INTEREST}

Authors declare no conflict of interest. 


\section{REFERENCES}

Ballester A.R., Lafuente M.T., GonzÁlez-CANDElas L., 2006. Spatial study of antioxidant enzymes, peroxidase and phenylalanine ammonia-lyase in the citrus fruit Penicillium digitatum interaction. Postharvest Biol. Technol. 39(2), 115-124.

BRADFORD M.M., 1976. A rapid and sensitive method for the quantitation of microgram quantities of protein utilizing the principles of protein-dye binding. Anal. Biochem. 72(1-2), 248-254.

CaO J., Yan J., Zhao Y., Jiang W., 2013. Effects of postharvest salicylic acid dipping on Alternaria rot and disease resistance of jujube fruit during storage. J. Sci. Food Agric. 93(13), 3252-3258.

Ceylan R., Sayin C., Özkan B., Akpinar M., İlbasmiş E., 2018. Comparative advantage analysis for Turkish grape and cherries export market. Int. J. Agric. Forest. Life Sci. 2(2), 75-86.

Coseteng M.Y., Lee C.Y., 1987. Changes in apple polyphenoloxidase and polyphenol concentrations in relation to degree of browning. J. Food Sci. 52(4), 985-989.

Dessalegn Y., Ayalew A., Woldetsadik K., 2013. Integrating plant defense inducing chemical, inorganic salt and hot water treatments for the management of postharvest mango anthracnose. Postharvest Biol. Technol. 85, 83-88.

Droby S., Vinokur V., Weiss B., Cohen L., Daus A., Goldschmidt E.E., Porat R., 2002. Induction of resistance to Penicillium digitatum in grapefruit by the yeast biocontrol agent Candida oleophila. Phytopathol. 92(4), 393-399.

ECKerT J.W., EAKs I.L., 1989. Postharvest disorders and diseases of citrus fruits. In: The Citrus Industry: History, World Distribution, Botany, and Varieties, Vol. 5, W. Reuther (Ed.), University of California, Division of Agricultural and Natural Resources, Richmond, USA, 179-260.

He J., Ren Y., Chen C., Liu J., Liu H., Pei Y., 2017. Defense responses of salicylic acid in mango fruit against postharvest anthracnose, caused by Colletotrichum gloeosporioides and its possible mechanism. J. Food Safety 37(1): e12294.

Iqbal Z., Singh Z., Khangura R., Ahmad S., 2012. Management of citrus blue and green moulds through application of organic elicitors. Australasian Plant Pathol. 41(1), 69-77.

Kahramanoglu I., Usanmaz S., Alas T., Helvaci M., Askin A., 2018. Fungicides effect on the heart root infestations at pomegranate fruit. Int J Agric Forest. Life Sci. 2(2), 1-6.

Kinay P., Mansour M.F., Gabler F.M., Margosan D.A., Smilanick J.L., 2007. Characterization of fungicide-resistant isolates of Penicillium digitatum collected in California. Crop Prot. 26(4), 647-656.

KuĆ J., 2001. Concepts and direction of induced systemic resistance in plants and its application. Eur. J. Plant Pathol. 107(1), 7-12.
Kumar V.B.A., Mohan T.C.K., Murugan K., 2008. Purification and kinetic characterization of polyphenol oxidase from Barbados cherry (Malpighia glabra L.). Food Chem. 110(2), 328-333.

Lee C.Y., Kagan V., JaWorski A.W., Brown S.K., 1990. Enzymic browning in relation to phenolic compounds and polyphenoloxidase activity among various peach cultivars. J. Agric. Food Chem. 38(1), 99-101.

Liu F., Tu K., Shao X., Zhao Y., Tu S., Su J., et al., 2010. Effect of hot air treatment in combination with Pichia guilliermondii on postharvest anthracnose rot of loquat fruit. Postharvest Biol. Technol. 58(1), 6571.

Louw J.P., Korsten L., 2015. Pathogenicity and host susceptibility of Penicillium spp. on citrus. Plant Dis. 99(1), 21-30.

Macarisin D., Cohen L., Eick A., Rafael G., Belausov E., Wisniewski M., et AL., 2007. Penicillium digitatum suppresses production of hydrogen peroxide in host tissue during infection of citrus fruit. Phytopathol. 97(11), 1491-1500.

Mandal S., Mallick N., Mitra A., 2009. Salicylic acid-induced resistance to Fusarium oxysporum $\mathrm{f}$. sp. lycopersici in tomato. Plant Physiol. Biochem. 47(7), 642-649.

Masood A., Saeed S., Iqbal N., Malik M.T., Kazmi M.R., 2010. Methodology for the evaluation of symptoms severity of mango sudden death syndrome in Pakistan. Pak. J. Bot. 42(2), 1289-1299.

Meena B., Marimuthu T., Velazhahan R., 2001. Salicylic acid induces systemic resistance in groundnut against late leaf spot caused by Cercosporidium personatum. J. Mycol. Plant Pathol. 31(2), 139-145.

Mohammadi M., Kazemi H., 2002. Changes in peroxidase and polyphenol oxidase activities in susceptible and resistant wheat heads inoculated with Fusarium graminearum and induced resistance. Plant Sci. 162(4), 491-498.

Moscoso-Ramírez P.A., Palou L., 2013. Evaluation of postharvest treatments with chemical resistance inducers to control green and blue molds on orange fruit. Postharvest Biol. Technol. 85, 132-135.

Nantawanit N., Chanchaichaovivat A., PaniJpan B., Ruenwongsa P., 2010. Induction of defense response against Colletotrichum capsici in chili fruit by the yeast Pichia guilliermondii strain R13. Biol. Control 52(2), 145-152.

Ojaghian M.R., Almoneafy A.A., Qi Cui Z., Xie G.L., Zhang J., Shang C., et Al., 2013. Application of acetyl salicylic acid and chemically different chitosans against storage carrot rot. Postharvest Biol. Technol. 84, 51-60.

Ottmann C., Luberacki B., KüFner I., КосH W., BrunNer F., Weyand M., ET AL., 2009. A common toxin fold mediates microbial attack and plant defense. PNAS 106(25), 10359-10364. 
Panebianco S., Vitale A., Polizzi G., Scala F., Cirvilleri G., 2015. Enhanced control of postharvest citrus fruit decay by means of the combined use of compatible biocontrol agents. Biol. Control 84, 1927.

Qin G.Z., Tian S.P., Xu Y., Wan Y.K., 2003. Enhancement of biocontrol efficacy of antagonistic yeasts by salicylic acid in sweet cherry fruit. Physiol. Mol. Plant Pathol. 62(3), 147-154.

ShaAt M.N.M., Galal A.A., 2004. Response of citrus fruits to pre-harvest antioxidant spraying and infection with Alternaria fruit rot and green mould. Ann. Agr. Sci. (Cairo) 49, 747-758.

Siegel B.Z., Galston A.W., 1967. The isoperoxidases of Pisum sativum. Plant Physiol., 42, 221-226.

Sticher L., Mauch-Mani B., Métraux J.P., 1997. Systemic acquired resistance. Ann. Rev. Phytopathol. 35(1), 235-270.

Strobel N.E., Porter L.A., 2005. Salicylate inhibits growth of plant-pathogenic fungi and synergistically enhances the activity of other antifungal materials in vitro. J. Kentucky Acad. Sci. 66(2), 118-128.

Sukorini H., Sangchote S., Khewkhom N., 2013. Control of postharvest green mold of citrus fruit with yeasts, medicinal plants, and their combination. Postharvest Biol. Technol. 79, 24-31.

Tareen M.J., Abbasi N.A., Hafiz I.A., 2012. Postharvest application of salicylic acid enhanced antioxidant enzyme activity and maintained quality of peach cv.
'Flordaking' fruit during storage. Sci. Hortic. 142, 221-228.

Torres M.A., Jones J.D.G., DANGL J.L., 2006. Reactive oxygen species signaling in response to pathogens. Plant Physiol. 141(2), 373-378.

Vilanova L., Viñas I., Torres R., Usall J., Jauset A.M., TEIXIDó N., 2012. Infection capacities in the orangepathogen relationship: compatible (Penicillium digitatum) and incompatible (Penicillium expansum) interactions. Food Microbiol. 29(1), 56-66.

Wyatt M.K., PARISH M.E., 1995. Spore germination of citrus juice-related fungi at low temperatures. Food Microbiol. 12, 237-243.

Xu X.B., QIN G.Z., TIAN S.P., 2008. Effect of microbial biocontrol agents on alleviating oxidative damage of peach fruit subjected to fungal pathogen. Int. J. Food Microbiol. 126(1-2), 153-158.

YAO H., Tian S., 2005. Effects of pre- and post-harvest application of salicylic acid or methyl jasmonate on inducing disease resistance of sweet cherry fruit in storage. Postharvest Biol. Technol. 35(3), 253-262.

Yu T., Zhang H.Y., Li X.L., Zheng X.D., 2008. Biocontrol of Botrytis cinerea in apple fruit by Cryptococcus laurentii and indole-3-acetic acid. Biol. Control 46(2), 171-177.

ZHeng X., Tian S., 2006. Effect of oxalic acid on control of postharvest browning of litchi fruit. Food Chem. 96(4), 519-523.

Received November 8, 2018; accepted February 6, 2019 